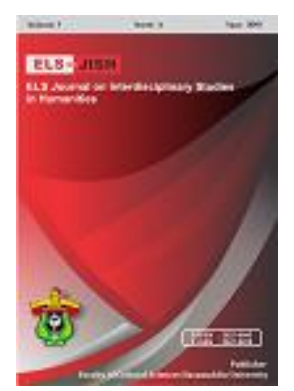

\title{
ELS-JISH
}

ELS Journal on Interdisciplinary Studies on Humanities

Volume 2 Issue 4, 2019

ISSN (print) : 2621-0843

ISSN (online) : 2621-0835

Homepage : http://journal.unhas.ac.id/index.php/jish

\section{Development of Work Sheets for Students (LKPD) in Writing Explanation Text}

\author{
Charlina $^{1}$, Elvrin Septyanti ${ }^{2}$ \\ 1charlina@lecturer.unri.ac.id
}

\begin{abstract}
This study aims to describe the results of product trials based on the development of needs analysis results and product validation results that have been assessed. The product developed was LKPD in writing explanatory texts for high school students. This research is part of research and development $(R \& D)$ research. The method used in this research is qualitative and quantitative. The Products tested on students on a small scale at class XI student of Senior High School Dharma Loka Pekanbaru. Data collection techniques were carried out through the questionnaire and test stages. Questionnaires were given to students to describe the quality of teaching materials (LKPD) that had been made by filling out questionnaire instruments. The test is given to students in accordance with the instructions and questions in the LKPD, so a score is obtained based on established assessment criteria. Data obtained, analyzed through SPSS. The results of the data analysis provide an overview of the aspects of content eligibility, aspects of language readability, presentation of material, and graphics, which have powerful correlations for the preparation of LKPD. This is indicated by the level of correlation of the aspect of content eligibility 0.852 with a significance level of $0.000<0.5$; aspects of language readability 0.759 with a significance level of $0.000<0.5$; presentation of material 0.979 with a significance level of $0.000<0.5$; and graphics 0.702 with a significance level of $0,000<0.5$; and graphics 0.702 with a significance level of $0,000<0.5$.
\end{abstract}

Keywords: Development of LKPD, Writing, Explanatory Text

How to cite: Charlina \& Septyanti, E. (2019). Development of Work Sheets for Students (LKPD) in Writing Explanation Text. ELS Journal on Interdisciplinary Studies in Humanities, 2(4), 515-528

\section{Introduction}

The era of the 2013 curriculum, teachers play an important role in the implementation of learning in schools. The most basic role is the teacher as a facilitator must be able to prepare learning in class with planned. Maturely, all these aspects can direct learning activities in class well and effectively. Moreover, the ability of the 21 st century today, challenges teachers, especially teachers, to invest a

\footnotetext{
${ }^{1,2}$ Riau University, Indonesia 
maximum of 4 points: critical thinking, communicative, collaborative, and creativity (Sugiyarti et al, 2018).

The ideal learning activities become a hope for students. Simple learning can be seen based on 3 activities: planning, implementing, and evaluating. A clear learning plan includes lesson plans that are always modified according to the needs of the class, the selection of methods or models of learning that are also in accordance with the conditions of the class, preparation of teaching material that is representative of the circumstances in each region, the design of LKPD that is appropriate for the needs of knowledge, skills, and student attitudes. Implementation in learning can be seen based on the directed process. This can provide good motivation to learn also for students. Targeted activities, provide a good stimulus for students so that students know the learning objectives that must be passed. In the learning evaluation stage, at each meeting, the teacher can utilize LKPD so that the learning outcomes at each meeting are in accordance with both the basic and core competencies that students must achieve.

Student worksheets (LKPD) become an alternative for teachers so that learning outcomes according to basic competencies can be achieved. LKPD in the form of student work guides that serve to facilitate students in implementation so that LKPD has a role in increasing student learning activities (Haqsari, 2014). In the General Guidelines for the Development of Teaching Materials compiled by the Ministry of National Education in Prastowo (cited Sari et al, 2017), student work sheets are sheets of work that must be done by students. Activity sheets are usually in the form of instructions or steps to complete a task. The task given must be clear what basic competencies will be achieved. The benefits of this fishbone diagram can help to find the root cause of the problem in a user friendly, user friendly tool preferred by people in the manufacturing industry where the process there is known to have a wide variety of variables that have the potential to cause problems (Purba, 2008).

So far, the preparation of LKPD has been carried out by the MGMP team and / or many publishers. The number of publishers and authors of Indonesian textbooks is very possible for the emergence of the presentation of material with a style of language that affects students' understanding. Of course the existing facilities like this were found to be weak in the preparation of LKPD. The nature of LKPD will not be representative of the situation in each school area. In fact, it is feared that textbooks are not suitable for use by students and teachers because they are not in accordance with the applicable curriculum (Kasih, 2016).

The explanatory text can be defined as a text that contains a detailed description of a natural or social phenomenon that occurs based on the pattern of causality. In addition, it also outlines the chronology that causes an event to occur and is associated with other events through several statements (Syaidati et al, 2016).

\section{Method}

This research is part of $R \& D$ research. This research is the final stage in product development, which is a small-scale product trial. The method used is qualitative and descriptive. The sample of this research were 30 students of CLASS XI from Dharma Loka High School. Data was collected based on questionnaire and 
test distribution. Students are given LKPD and assess based on product assessment rubric with a questionnaire assessment range 1-5. Number 1: criteria are not very good, 2: not good, 3: good enough, 4: good, and 5: very good. Students are also asked to work on questions in the LKPD. Furthermore, the results of answers in LKPD are assessed with scores that have been converted according to the research criteria set out in LKPD. The data that has been obtained is processed in SPSS to describe the quality of the LKPD that has been designed. In addition, the product trial score obtained is described as the usefulness of the LKPD.

\section{Results}

Research on the development of student worksheets (LKPD) writes explanatory texts based on fishbone diagrams for senior high school level based on several stages. The stages include: needs analysis, content design and appearance, product validation from media and material experts, revisions, product trials, final revisions, and final LKPD. The details of the stages in question namely,

\subsection{Need Analysis}

In this needs analysis, LKPD is designed based on the findings and needs expected by students and teachers. During this time, in the implementation of teaching and learning activities, students are fixated on the Student Worksheet (LKPD) that does not meet the content standards. For example, in KD writing explanatory texts, students are asked to write explanatory texts with causal relationships. Some of the questions presented tend to test aspects of knowledge related to explanatory texts. Supposedly, the instructions given to students are not only in the aspect of knowledge but also in the aspect of expertise. In addition, the availability of LKPD that is done by students is based on the tasks in the textbooks of the subjects. Based on the results of the needs analysis $51.2 \%$ of students have not experienced a fishbone strategy in the learning process of writing and $88.2 \%$ of students want a LKPD that is representative and in accordance with the content standards in the basic competencies in the current curriculum (Charlina and Septyanti, 2019).

\subsection{Design the contents and appearance}

The design of the contents include;
a) Title
b) Study instructions
c) Basic competence
d) Supporting information
e) Exercise
f) Rubric and assessment criteria 


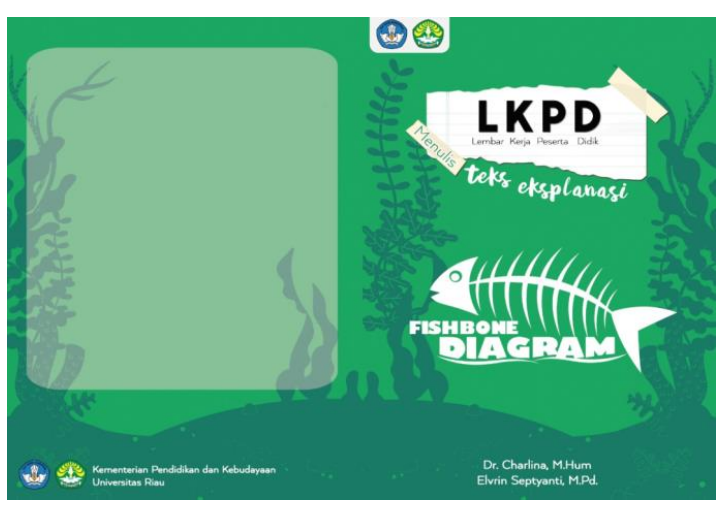

Figure 1. Front page LKPD Writing explanatory texts
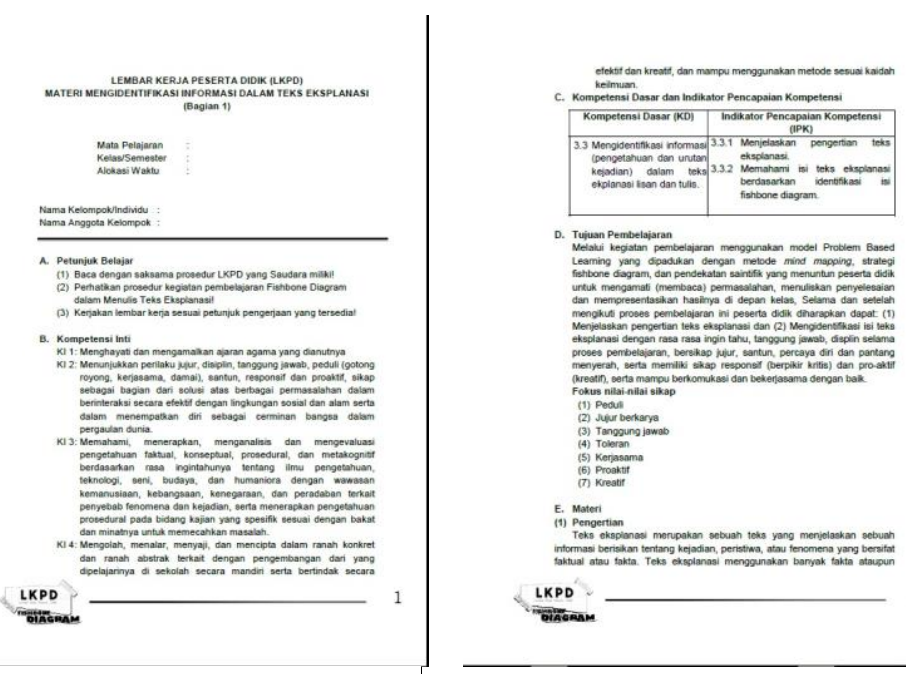

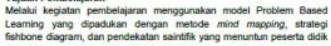
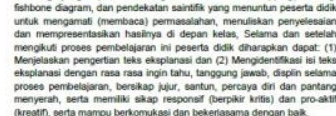

Fokus natainatiat atik

(i) Peacis

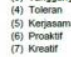

E. Materi

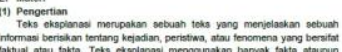

LKPD.

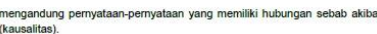

Teks essolanasi di antaranyy mempunya tujum

a) Merijelaskan tenomenen yang terjadi

(2) Ciri-ciri Teks Eksplanasi Kompleks
Cir-cini teks esspolanasi kompleks.

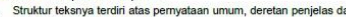

interpertasi
b. Memuat intormasi berdasarkan takta atau faktual.

Faktualnya memuat informasi yang bersifat keilmuan.
Fokus pada hal unum, bukan partisipan manusiala misalyya, gempa

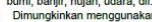

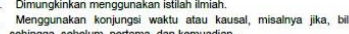

g. Behingas, sebelum, pertama, dan kemuad

F. Langkah-langkah Kegiatan Pembelajaran

Dalam mengembangkan teks eksplanasi, perhatkkahn langkah-langkkat
Fishbone Diagram berkutt

Fishbone diagram (diagram tulang ikan - karena bentuknya seperl

Diagram diperkenalkan oleh Dr. Kaoru lshikawa, seorang ahil pengendalian

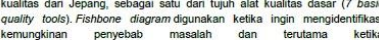

kemungkinan penyebab masalah dan terutama ketich

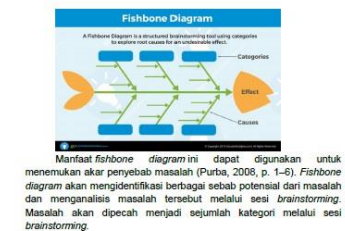

Masalah akn
brainstorrine
and

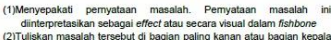

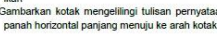

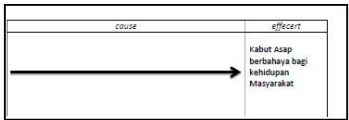

LKPD

LKPD 


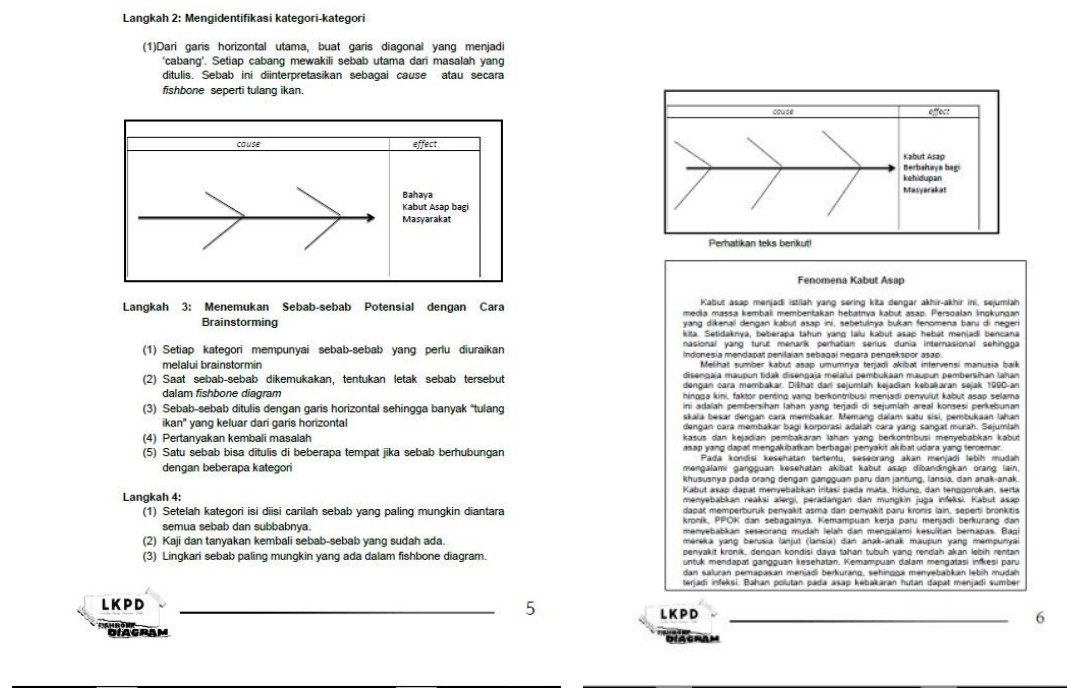

Figure 2. Section contents of LKPD Writing Explanation Text

\subsection{Expert Validation}

LKPD validation is conducted to determine and evaluate the performance and feasibility of the developed LKPD. LKPD validation was carried out by 2 validators, namely media experts and material experts. Media expert is a lecturer who knows and is an expert in the field of media. Material experts are Indonesian language teachers who know well or master the material to write explanatory texts in high schools.

Table 1. Percentage of Response Reports on Media Aspects

\begin{tabular}{ccc}
\hline Scale & Category & Percentage \\
\hline 1 & Not very good & 0 \\
\hline 2 & Not good & 0 \\
\hline 3 & Goog enough & 0 \\
\hline 4 & Good & 24.14 \\
\hline 5 & Very Good & 75.86 \\
\hline & Total & 100
\end{tabular}

The table corroborates above is the good categorization statement $24.14 \%$ and very good $75.86 \%$. According to the mastery learning theory explaining the $75 \%$ standard can be said to be feasible as a basis for decision making.

Tabel 2. Mean Dimension of Media Observation

\begin{tabular}{lll}
\hline \multicolumn{1}{c}{ Dimension } & Mean & Category \\
\hline Eligibity & 4.70 & Very good \\
\hline Linguistic & 4.86 & Very good \\
\hline Dishes & 4.67 & Very good \\
\hline Gemoghrapy & 4.83 & Very good \\
\hline
\end{tabular}

Statements related to the media are based on four dimensions of observation, namely the feasibility dimension, the linguistic dimension, the presentation dimension, and the graphic dimension. Each of these dimensions is in a very good category. This is indicated by the mean feasibility (4.70), the linguistic dimension (4.86), the presentation dimension (4.67), and the graphic dimension (4.83). 
Table 3. Percentage of Response Statement Material Aspects

\begin{tabular}{ccc}
\hline Scale & cateory & Persentage \\
\hline 1 & Not very good & 0 \\
\hline 2 & Not good & 0 \\
\hline 3 & Enough good & 0 \\
\hline 4 & Good & 36.84 \\
\hline 5 & Very Good & 63.16 \\
\hline
\end{tabular}

The table above corroborates the categorized statements of good $36.84 \%$ and very good $63.16 \%$. Aziz (1998) suggests all aspects of the instrument must be categorized well.

Table 4. Mean Dimensions of Material Observation

\begin{tabular}{lll}
\hline \multicolumn{1}{c}{ Dimension } & Mean & Category \\
\hline Eligibity & 4.67 & Very good \\
\hline Linguistic & 4.75 & Very good \\
\hline Dishes & 4.60 & Very good \\
\hline Gemoghrapy & 4.50 & Very good \\
\hline
\end{tabular}

Statements related to the media are based on four dimensions of observation, namely the feasibility dimension, the linguistic dimension, the presentation dimension, and the graphic dimension. Each of these dimensions is in a very good category. This is indicated by the mean content eligibility (4.67), linguistic dimension (4.75), presentation dimension (4.60), and graphic dimension (4.50). Aziz (1998) each dimension in research must be categorized well so that it is suitable for use in data collection. In addition, something is categorized according to the measurement design (Robinson-Kurpius \& Stafford, 2006).

\section{4 LKPD Revision}

Revisions were made to improve the LKPD in accordance with comments and suggestions during validation. The suggestions given by lecturers (media experts) and teachers (material experts) include:

a) Operational verbs in learning indicators must be improved

b) Addition of design drawings, colors in LKPD

c) Criteria for evaluating tasks in LKPD are clarified

\subsection{Product trials}

\subsubsection{LKPD assessment}

A trial was conducted to determine students' responses as users of the LKPD. Users are senior high school students in Pekanbaru Dharma High School, as many as 30 people. Student assessment data obtained by using a questionnaire instrument. The results of the LKPD assessment by 30 users can be seen in the following table.

Table 5. $1^{\text {st }}$ Statement Indicator of LKPD Assessment

\begin{tabular}{ccc}
\hline Category & Frequency & Percentage \\
\hline Enough good & 10 & 32,3 \\
\hline Good & 15 & 48,4 \\
\hline Very good & 6 & 19,4 \\
\hline Total & 31 & 100,0 \\
\hline
\end{tabular}


The data above relates to basic competences which identifying information (knowledge and sequence of events) in the explanatory text both oral and written obtained quite good category $32.3 \%$; good $48.4 \%$; and very good $19.4 \%$. The orientation of respondents used more of a good level approach to the statement. This data provides interpretation that not all respondents understand well about the SK / $\mathrm{KI}$ and $\mathrm{KD}$ provinces in learning to identify information and sequence of events in explanatory texts.

Table 6. $2^{\text {nd }}$ Statement Indicator of LKPD Assessment

\begin{tabular}{ccc}
\hline Category & Frequency & Percentage \\
\hline Not good & 2 & 6,5 \\
\hline Enough good & 11 & 35,5 \\
\hline Good & 13 & 41,9 \\
\hline Very good & 5 & 16,1 \\
\hline Total & 31 & 100,0 \\
\hline
\end{tabular}

The data above relates to KD which identifying information (knowledge and sequence of events) in explanatory texts both oral and written. This data includes the presentation of material that is easily understood in LKPD. Based on table 8, it was found that not good category was $6.6 \%$, enough good at $35.5 \%$; good $41.9 \%$; and very good $16.1 \%$. The orientation of respondents used more of a good level approach to the statement.

Table 7. $3^{\text {rd }}$ Statement Indicator of LKPD Assessment

\begin{tabular}{crr}
\hline Category & Frequency & Percentage \\
\hline Enough good & 11 & 35,5 \\
\hline Good & 11 & 35,5 \\
\hline Very good & 9 & 29,0 \\
\hline Total & 31 & 100,0 \\
\hline
\end{tabular}

Statements related to the material wrangling in LKPD. Table 9 shows that the good enough category is $35.5 \%$; good $35.5 \%$; and very good $29.0 \%$. The orientation of respondents used more of a good level approach to the statement.

Table 8. $4^{\text {th }}$ Statement Indicator of LKPD Assessment

\begin{tabular}{ccc}
\hline Category & Frequency & Percentage \\
\hline Enough good & 5 & 16,1 \\
\hline Good & 13 & 41,9 \\
\hline Very good & 13 & 41,9 \\
\hline Total & 31 & 100,0 \\
\hline
\end{tabular}

The statement above relates to the suitability of the material presented with moral, social and social values. Table 10 shows that the good enough category is $16.1 .5 \%$; good $41.9 \%$; and very good $41.9 \%$. The orientation of respondents used more approach at a very good level to the statement.

Table 9. $5^{\text {th }}$ Statement Indicator of LKPD Assessment

\begin{tabular}{crr}
\hline Category & Frequency & Percentage \\
\hline Enough good & 10 & 32,3 \\
\hline Good & 10 & 32,3 \\
\hline Very good & 11 & 35,5 \\
\hline Total & 31 & 100,0 \\
\hline
\end{tabular}


The statement above relates to the paragraphs and sentences used in LKPD that are clear and unambiguous. Table 11 shows that the good enough category is $32.3 \%$; good $32.3 \%$; and very good $35.5 \%$. The orientation of respondents used more approach at a very good level to the statement.

Table 10. $6^{\text {th }}$ Statement Indicator of LKPD Assessment

\begin{tabular}{lrr}
\hline \multicolumn{1}{c}{ Category } & Frequency & Percentage \\
\hline Enough good & 11 & 35,5 \\
\hline Good & 11 & 35,5 \\
\hline Very good & 9 & 29,0 \\
\hline Total & 31 & 100,0 \\
\hline
\end{tabular}

The statements above relating to sentences and paragraphs in LKPD are easy to understand. Table 12 shows that the good enough category is $35.5 \%$; good $35.5 \%$; and very good $29.0 \%$. The orientation of respondents used more of a good level approach to the statement.

Table 11. $7^{\text {th }}$ Statement Indicator of LKPD Assessment

\begin{tabular}{lrr}
\hline \multicolumn{1}{c}{ Category } & Frequency & Percentage \\
\hline Not good & 1 & 3,2 \\
\hline Enough good & 10 & 32,3 \\
\hline Good & 10 & 32,3 \\
\hline Very good & 10 & 32,3 \\
\hline Total & 31 & 100,0 \\
\hline
\end{tabular}

The statement above relating to language in LKPD is communication. Table 13 shows that not good category was 3.2\%, good enough $32.3 \%$; good $32.3 \%$; and very good $32.2 .0 \%$. The average respondent orientation uses a good level approach to the statement.

Table 12. $8^{\text {th }}$ Statement Indicator of LKPD Assessment

\begin{tabular}{lrr}
\hline \multicolumn{1}{c}{ Category } & Frequency & Percentage \\
\hline Not good & 4 & 12,9 \\
\hline Enough good & 10 & 32,3 \\
\hline Good & 10 & 32,3 \\
\hline Very good & 7 & 22,6 \\
\hline Total & 31 & 100,0 \\
\hline
\end{tabular}

The statements above relating to the presentation of the material in this book create a pleasant atmosphere. Table 14 shows not good category obtained $12.9 \%$, good enough 32.3\%; good 32.3\%; and very good $22.6 \%$. The average respondent orientation uses a good level approach to the statement.

Table 13. $9^{\text {th }}$ Statement Indicator of LKPD Assessment

\begin{tabular}{lrr}
\hline \multicolumn{1}{c}{ Category } & Frequency & Percentage \\
\hline Not good & 2 & 6,5 \\
\hline Enough good & 12 & 38,7 \\
\hline Good & 9 & 29,0 \\
\hline Very good & 8 & 25,8 \\
\hline Total & 31 & 100,0 \\
\hline
\end{tabular}

The statement above relates to the presentation of the material in this book provides an opportunity to carry out independently. Table 15 shows the $6.5 \%$ not good category, $38.7 \%$ good enough; good $29.0 \%$; and very good $25.8 \%$. The 
orientation of respondents is more likely to use a good level approach to the statement.

Table 14. $10^{\text {th }}$ Statement Indicator of LKPD Assessment

\begin{tabular}{lcc}
\hline \multicolumn{1}{c}{ Category } & Frequency & Percentage \\
\hline Enough good & 9 & 29,0 \\
\hline Good & 8 & 25,8 \\
\hline Very good & 14 & 45,2 \\
\hline Total & 31 & 100,0 \\
\hline
\end{tabular}

The statements above relating to the presentation of the material in this book can require students to think critically. Table 16 shows that the good enough category is 29.0\%; good 25.8\%; and very good $45.2 \%$. The orientation of respondents is more likely to use a very good level of approach to the statement.

Table 15. $11^{\text {th }}$ Statement Indicator of LKPD Assessment

\begin{tabular}{lcc}
\hline \multicolumn{1}{c}{ Category } & Frequency & Percentage \\
\hline Not good & 1 & 3,2 \\
\hline Enough good & 7 & 22,6 \\
\hline Good & 14 & 45,2 \\
\hline Very good & 9 & 29,0 \\
\hline Total & 31 & 100,0 \\
\hline
\end{tabular}

The statements above relating to the presentation of material in this book can require students to think creatively. Table 17 shows that not good category was $3.2 \%$, quite good at $22.6 \%$; good $45.2 \%$; and very good $29.0 \%$. The orientation of respondents is more likely to use a good level approach to the statement.

Table 16. $12^{\text {th }}$ Statement Indicator of LKPD Assessment

\begin{tabular}{lcc}
\multicolumn{1}{c}{ Category } & Frequency & Percentage \\
\hline Not good & 1 & 3,2 \\
\hline Enough good & 10 & 32,3 \\
\hline Good & 11 & 35,5 \\
\hline Very good & 9 & 29,0 \\
\hline Total & 31 & 100,0 \\
\hline
\end{tabular}

The statements above relating to the presentation of the material in this book can require students to think innovatively. Table 18 shows that not good category was $3.2 \%$, quite good $32.3 \%$; good $35.5 \%$; and very good $29.0 \%$. The orientation of respondents is more likely to use a good level approach to the statement.

Table 17. $13^{\text {rd }}$ Statement Indicator of LKPD Assessment

\begin{tabular}{lcc}
\hline \multicolumn{1}{c}{ Category } & Frequency & Percentage \\
\hline Enough good & 6 & 19,4 \\
\hline Good & 14 & 45,2 \\
\hline Very good & 11 & 35,5 \\
\hline Total & 31 & 100,0 \\
\hline
\end{tabular}

The statements above relating to the presentation of material in this book can require students to dig up information. Table 19 shows that the good enough category is $19.4 \%$; good $45.2 \%$; and very good $35.5 \%$. The orientation of respondents is more likely to use a good level approach to the statement. 
Table 18. $14^{\text {th }}$ Statement Indicator of LKPD Assessment

\begin{tabular}{lrr}
\hline \multicolumn{1}{c}{ Category } & Frequency & Percentage \\
\hline Not good & 2 & 6,5 \\
\hline Enough good & 9 & 29,0 \\
\hline Good & 9 & 29,0 \\
\hline Very good & 11 & 35,5 \\
\hline Total & 31 & 100,0 \\
\hline
\end{tabular}

The statements above relating to the presentation of the material in this book can require students to make decisions. Table 20 shows that the category of unfavorable is $6.5 \%$, good enough is $29.0 \%$; good $29.0 \%$; and very good $35.5 \%$. The orientation of respondents is more likely to use a very good level of approach to the statement.

Table 19. $15^{\text {th }}$ Statement Indicator of LKPD Assessment

\begin{tabular}{lrr}
\hline \multicolumn{1}{c}{ Category } & Frequency & Percentage \\
\hline Not good & 3 & 9,7 \\
\hline Enough good & 9 & 29,0 \\
\hline Good & 11 & 35,5 \\
\hline Very good & 8 & 25,8 \\
\hline Total & 31 & 100,0 \\
\hline
\end{tabular}

The statements above relating to the presentation of the material in this book can require students to communicate between students. Table 21 shows not good category obtained $9.7 \%$, good enough $29.0 \%$; good $35.5 \%$; and very good $25.8 \%$. The orientation of respondents is more likely to use a good level approach to the statement

Table 20. $16^{\text {th }}$ Statement Indicator of LKPD Assessment

\begin{tabular}{lrr}
\hline \multicolumn{1}{c}{ Category } & Frequency & Percentage \\
\hline Not good & 4 & 12,9 \\
\hline Enough good & 8 & 25,8 \\
\hline Good & 9 & 29,0 \\
\hline Very good & 10 & 32,3 \\
\hline Total & 31 & 100,0 \\
\hline
\end{tabular}

The statements above relating to the presentation of the material in this book can provide a sample presentation to clarify student understanding. Table 22 shows that not good category is $12.9 \%$, good enough $25.8 \%$; good $29.0 \%$; and very good $32.3 \%$. The orientation of respondents is more likely to use a very good level of approach to the statement.

Table 21. $17^{\text {th }}$ Statement Indicator of LKPD Assessment

\begin{tabular}{lrr}
\hline \multicolumn{1}{c}{ Category } & Frequency & Percentage \\
\hline Not good & 1 & 3,2 \\
\hline Enough good & 12 & 38,7 \\
\hline Good & 11 & 35,5 \\
\hline Very good & 7 & 22,6 \\
\hline Total & 31 & 100,0 \\
\hline
\end{tabular}

The statements above relating to the presentation of the material in this book provide the presentation of charts and pictures to make it easier for students to understand the material. Table 23 shows that not good category was $3.2 \%$, good 
enough $38.7 \%$; good $35.5 \%$; and very good $22.6 \%$. Orientation of respondents is more likely to use an approach at a good enough level to the statement.

Table 22. $18^{\text {th }}$ Statement Indicator of LKPD Assessment

\begin{tabular}{lrr}
\hline \multicolumn{1}{c}{ Category } & Frequency & Percentage \\
\hline Not good & 1 & 3,2 \\
\hline Enough good & 11 & 35,5 \\
\hline Good & 8 & 25,8 \\
\hline Very good & 11 & 35,5 \\
\hline Total & 31 & 100,0 \\
\hline
\end{tabular}

The statements above relating to the presentation of the material in this book provide the presentation of charts and pictures to make it easier for students to understand the material. Table 24 shows that not good category was $3.2 \%$, good enough at $35.5 \%$; good $25.5 \%$; and very good $35.5 \%$. The orientation of respondents is more likely to use a very good level of approach to the statement.

Table 23. $19^{\text {th }}$ Statement Indicator of LKPD Assessment

\begin{tabular}{lrr}
\hline \multicolumn{1}{c}{ Category } & Frequency & Percentage \\
\hline Enough good & 10 & 32,3 \\
\hline Good & 10 & 32,3 \\
\hline Very good & 11 & 35,5 \\
\hline Total & 31 & 100,0 \\
\hline
\end{tabular}

The statement above relates to the presentation of the material in this book containing practice tests and evaluations that can test student understanding. Table 25 shows that the good enough category is $32.3 \%$; good $32.3 \%$; and very good $35.5 \%$. The orientation of respondents is more likely to use a very good level of approach to the statement.

Table 24. $20^{\text {th }}$ Statement Indicator of LKPD Assessment

\begin{tabular}{lrr}
\hline \multicolumn{1}{c}{ Category } & Frequency & Percentage \\
\hline Not good & 3 & 9,7 \\
\hline Enough good & 12 & 38,7 \\
\hline Good & 5 & 16,1 \\
\hline Very good & 11 & 35,5 \\
\hline Total & 31 & 100,0 \\
\hline
\end{tabular}

The statement above relates to the position of a balanced image between text and image. Table 26 shows not good category obtained $9.7 \%, 38.7 \%$ good enough; good $16.1 \%$; and very good $35.5 \%$. The orientation of respondents is more likely to use a very good level of approach to the statement.

Table 25. $21^{\text {st }}$ Statement Indicator of LKPD Assessment

\begin{tabular}{lrr}
\hline \multicolumn{1}{c}{ Category } & Frequency & Percentage \\
\hline Not good & 1 & 3,2 \\
\hline Enough good & 14 & 45,2 \\
\hline Good & 7 & 22,6 \\
\hline Very good & 9 & 29,0 \\
\hline Total & 31 & 100,0 \\
\hline
\end{tabular}

The statement above relates to the size, shape, and color of the picture attracting students in reading and learning. Table 27 shows that not good category was $3.2 \%$, good enough $45.2 \%$; good $22.6 \%$; and very good $29.0 \%$. Orientation of 
respondents is more likely to use an approach at a good enough level to the statement.

Table 26. $22^{\text {nd }}$ Statement Indicator of LKPD Assessment

\begin{tabular}{lrr}
\hline \multicolumn{1}{c}{ Category } & Frequency & Percentage \\
\hline Not very good & 1 & 3,2 \\
\hline Enough good & 7 & 22,6 \\
\hline Good & 1 & 3,2 \\
\hline Very good & 22 & 71,0 \\
\hline Total & 31 & 100,0 \\
\hline
\end{tabular}

The statement above relates to the type and size of letters that are easy to read. Table 28 shows that the category of very bad 3.2\%, good enough $22.6 \%$; good $3.2 \%$; and very good $71.0 \%$. The orientation of respondents is more likely to use a very good level of approach to the statement.

Table 27. $23^{\text {rd }}$ Statement Indicator of LKPD Assessment

\begin{tabular}{lrr}
\hline \multicolumn{1}{c}{ Category } & Frequency & Percentage \\
\hline Not very good & 1 & 3,2 \\
\hline Enough good & 8 & 25,8 \\
\hline Good & 5 & 16,1 \\
\hline Very good & 17 & 54,8 \\
\hline Total & 31 & 100,0 \\
\hline
\end{tabular}

The statement above relates to the type and size of letters that are easy to read. Table 29 shows that the category of very bad $3.2 \%$, quite good $25.8 \%$; good $16.1 \%$; and very good $54.8 \%$. Orientation of respondents is more likely to use an approach at a very good level both to the statement.

\subsubsection{Dimensions of LKPD Aspects of writing explanatory texts}

At this stage, LKPD will be assessed by students. In addition, students are asked to work on questions in the LKPD.

Table 28. Dimensions of LKPD Aspects of writing explanatory texts

\begin{tabular}{lcccc}
\hline \multicolumn{1}{c}{ Statement } & N & Mean & $\begin{array}{c}\text { Standard } \\
\text { deviation }\end{array}$ & $\begin{array}{c}\text { Standar } \\
\text { Error }\end{array}$ \\
\hline Content Feasibility Aspect & 31 & 3.9355 & 0.63235 & 0.11357 \\
\hline Aspects of Language Readability & 31 & 3.9677 & 0.67449 & 0.12114 \\
\hline Presentation of Material & 31 & 3.9065 & 0.70664 & 0.12692 \\
\hline Graphic & 31 & 4.0323 & 0.78460 & 0.14092 \\
\hline
\end{tabular}

Based on these averages, the assessment aspects of LKPD Writing Explanation Texts are in the good category. Fitri (2018) competency standards as a determinant in learning, even as part of the needs in learning to present knowledge and skills to students. 
Table 29. Correlations to LKPD writing explanatory texts

\begin{tabular}{llll}
\hline \multicolumn{1}{c}{ Dimensi } & $\begin{array}{c}\text { Korelasion } \\
(\mathbf{r})\end{array}$ & $\begin{array}{c}\text { Signifcance } \\
(<\mathbf{0 , 5 )}\end{array}$ & Category \\
\hline Content Feasibility Aspect & $0,852^{* *}$ & 0,000 & Very strong \\
\hline Aspects of Language Readability & $0,759^{* *}$ & 0,000 & Very strong \\
\hline Presentation of Material & $0,979^{* *}$ & 0,000 & Very strong \\
\hline Graphic & $0,702^{* *}$ & 0,000 & Very strong \\
\hline
\end{tabular}

The results of the data analysis provide an overview of the aspects of content eligibility, aspects of language readability, presentation of material, and graphics which have very strong correlations for the preparation of LKPD. This is indicated by the level of correlation of the aspect of content eligibility 0.852 with a significance level of $0.000<0.5$; aspects of language readability 0.759 with a significance level of $0.000<0.5$; presentation of material 0.979 with a significance level of $0.000<0.5$; and graphics 0.702 with a significance level of $0,000<0.5$.

Based on the results of the analysis of statements in the preparation of LKPD, the designed LKPD was considered good so that this LKPD could be used by teachers and students.

\section{Discussion}

This research has followed the stages in development research. In the first stage, the researcher knows that the teachers have not implemented one of the strategies in writing especially fishbone strategy in writing skills at school. The results of the needs analysis, this strategy can be used as a foundation in the preparation of LKPD while introducing a fishbone diagram strategy to students and teachers. In the next stage, the content design and graphic design stages are arranged so that the material and instructions presented in the LKPD writing explanatory texts can be read and understood by students and teachers.

The validation results show that the LKPD still has weaknesses that must be revised before being used in high school. Suggestions obtained from students tend to be comments related to appearance and color in LKPD. Students tend to think that LKPD that has many colors is LKPD which is interesting so that in the next stage, LKPD experiences some improvements.

In the product trial phase to students, the results obtained are good. In general, LKPD can be accepted by teachers and students. This is consistent with the results obtained from the calculation of the correlation with LKPD writing the developed explanatory text.

\section{Conclusion}

The development of LKPD which has been tested on a small scale is considered good. This development is expected to be beneficial for the needs of teachers who have been constrained by the literature on LKPD writing explanatory texts. It is hoped that the LKPD can be applied in schools through community service 
activities so that it can be known for weaknesses. The weaknesses found will be the process of improvement and refinement of LKPD so that it can be used by teachers and students in schools.

\section{Acknowledgments}

Thank you FKIP Riau University for giving the research team the opportunity to develop an LKPD to write an explanatory text submitted through a research. Thank You To The Teachers And Students Who Helped In The Assessment And Suggestion of Repairing LKPD.

\section{References}

Aziz, A. A. (1998). Development of Moslem Religiosity Scale. North Zeeb Road: UMI.

Charlina dan Elvrin Septyanti. (2019). "Need Analysis of Development Work Sheet of Student (LKPD) in Writing Explanatory Text based on Fishbone Diagram". Proceeding of the SS9 \& $3^{\text {rd }}$ URICES, 2019, Pekanbaru, Indonesia.

Fitri, A. Z. (2018). Achieving Graduate Competency Standards: Impact of The Excellence Program. Jurnal Pendidikan Islam, 4 (1), 51-62.

Haqsari, Rizqi. (2014). "Pengembangan dan Analisis E-LKPD (Elektronik - Lembar Kerja Peserta Didik) Berbasis Multimedia pada Materi Mengoperasikan Software Spreadsheet". Skripsi. Yogyakarta: Universitas Negeri Yogyakarta.

Kasih, Belinda Purwita. (2016). "Kelayakan Isi Lembar Kerja Siswa Bahasa Indonesia SMA Kelas X Semester 2 Kurikulum 2013”. Skripsi. Solo: Universitas Muhamadiyah Surakarta.

Purba, H.H. (2008). "Diagram fishbone dari Ishikawa. Http://hadipurba.com/2008/09/25/diagram-fishbone-dariishikawa.html.

Sari, Fiqi Nurmanda, Nurhayati, dan Sungkowo Sutopo. (2017). "Pengembangan Lembar Kerja Peserta Didik (LKPD) Elektronik Teks Cerita Pendek Berbasis Budaya Lokal". Tesis. Palembang: Universitas Sriwijaya.

Sugiyarti, Lina, Alrahmat Arif, dan Mursalin. (2018). "Pembelajaran Abad 21 di SD". Prosiding Seminar dan Diskusi Nasional Pendidikan Dasar.

Syaidati dkk. (2016) "Pembelajaran Menulis Teks Eksplanasi Kompleks Berdasarkan Kurikulum 2013". Makalah. Pontianak: Untan. 